\title{
AS MEDIAÇÕES DO DISCURSO CONSERVACIONISTA EM RESERVAS DE DESENVOLVIMENTO SUSTENTÁVEIS DA AMAZÔNIA
}

\author{
MEDIATIONS THE SPEECH IN CONSERVATIONIST \\ RESERVATIONS FOR SUSTAINABLE DEVELOPMENT OF THE AMAZON \\ MEDIACIONES DEL DISCURSO CONSERVACIONISTA EN \\ RESERVAS PARA EL DESARROLLO SUSTENTABLE DE LA AMAZONÍA
}

\author{
Allan Soljenítsin Rodrigues \\ Dr, UFAM \\ allan_soljenitsin@yahoo.com.br \\ Grace Soares Costa \\ Mestra, FMF \\ grace.soares@gmail.com
}

\section{Resumo}

Tendo em vista que as ações de comunicação são estratégicas na criação e implementação de projetos sustentáveis envolvendo populações tradicionais na Amazônia, este artigo apresenta os resultados de uma pesquisa está focada nos processo de recepção e mediação do discurso conservacionista na comunidade de São Raimundo do Jarauá, localizada na Reserva de Desenvolvimento Sustentável Mamirauá (AM).

Palavras-chave: Amazônia. Comunicação. Meio Ambiente.

\begin{abstract}
Considering that the communication actions are strategic in creating and implementing sustainable projects involving traditional communities in the Amazon, this article presents the results of a search process is focused on the reception and mediation conservationist discourse in the community of São Raimundo Jarauá, located on Sustainable Development Reserve Mamirauá (AM).
\end{abstract}

Keywords: Amazon. Communication. Environment.

\section{Resumen}

Teniendo en cuenta que las acciones de comunicación son estratégicos en la creación e implementación de proyectos sustentables que involucran a las comunidades tradicionales de la Amazonia, en este artículo se presentan los resultados de una investigación con foco en el proceso de recepción y de mediación del discurso conservacionista en la comunidad de São Raimundo Jarauá, ubicado en Reserva de Desarrollo Sustentable Mamirauá (AM).

Palabras clave: Amazon. Comunicación. Medio Ambiente.

Esta obra está licenciada sob uma Licença Creative Commons 


\section{Comunicação e Sustentabilidade}

Um dos maiores problemas, se não o maior, a ser enfrentando pela sociedade reside na busca da conciliação da preservação do meio ambiente e a sustentabilidade das comunidades tradicionais. Para fazer frente a essa tarefa, organizações governamentais e não-governamentais têm investido tempo e dinheiro na busca de um modelo de desenvolvimento realmente sustentável para os "povos da floresta". No âmbito do poder público brasileiro, uma das respostas dadas às pressões nacionais e internacionais dos movimentos ambientalistas, iniciados nos anos 80, foi a criação de unidades de conservação com objetivo de preservar a biodiversidade de áreas consideradas de relevante interesse ecológico.

$\mathrm{Na}$ virada dos anos 80 para os 90 , houve uma mudança nos paradigmas do conservacionismo internacional e a idéia de preservação da biodiversidade em unidades de conservação passou a comportar também a participação das populações tradicionais. Dentro deste contexto, surgiram no Brasil as Reservas Extrativistas (Resex), no âmbito federal, e as Reservas de Desenvolvimento Sustentável, no âmbito estadual. A criação das Resex's e RDS's também foi fruto de pressões vindas da comunidade científica, dos ambientalistas (adeptos ao novo paradigma conservarcionista e dos movimentos sociais que representavam grupos como os seringueiros, no Acre, e as populações tradicionais da várzea amazônica, no Amazonas). Uma vez criadas, as unidades de conservação de uso sustentável tornaram-se experiências piloto de como proteger o meio ambiente e ao mesmo tempo proporcionar melhor qualidade de vida para as populações residentes nas reservas.

Desde o início os órgãos e entidades gestoras das Resex's e RDS's sabiam que uma das premissas para o sucesso na implementação das reservas seria a participação comunitária. Se acaso os moradores dos assentamentos não adotassem práticas compatíveis com a idéia do desenvolvimento sustentável e, por conseqüência, ficassem alheios a todas as mudanças comportamentais necessárias no estabelecimento de processos sustentáveis de usos dos recursos naturais, os projetos de implementação estariam fadados ao fracasso. Por isso, em várias unidades de conservação os gestores apostaram na comunicação como uma poderosa aliada no processo de "disseminação" 
das idéias conservacionistas norteadoras dos projetos das Resex's e RDS's. Os canais de comunicação mais utilizados foram o extensionismo, o rádio e a impressão de informativos e cartilhas dirigidas aos moradores com mensagens contendo o ideário conservacionista.

Tendo em vista o modelo de Jauss (1989), onde os receptores de uma mensagem não são considerados somente depositários de informações, mas também seres capazes de transformar significados levando em considerações fatores sócio-econômicos e culturais. Admite-se que há um conjunto de mediações ${ }^{1}$ interferindo na construção do espaçotempo do discurso conservacionista voltado para os comunitários. Mediações essas presentes no cotidiano dos receptores (moradores). Este artigo resume os resultados obtidos na dissertação de mestrado "Comunicação e Sustentabilidade: as mediações do discurso conservacionista em São Raimundo do jarauá”, apresentada ao Programa de Pós-graduação em Sociedade e Cultura na Amazônia (PPSCA), e cujo objeto de pesquisa foi delimitado no âmbito da identificação e análise das mediações do discurso conservacionista em uma comunidade caboclo-ribeirinha ${ }^{2}$ situada na RDS Mamirauá. ${ }^{3}$

Levando em consideração o que diz Martín-Barbero (1997), que as mediações também são possibilitadoras de mudanças que interferem nos processos sociais, a pesquisa tratou de investigar as mediações do discurso conservacionista feitas por moradores da reserva para aproximar-se dos motivos do sucesso da adoção de práticas sustentáveis em algumas comunidades da RDS Mamirauá. A comunidade escolhida para sediar a pesquisa foi São Raimundo do Jarauá, situada na RDS Mamirauá.

A pesquisa desenvolvida partiu dos estudos da recepção do discurso conservacionista levando em conta as mediações das práticas culturais e cotidianas dos indivíduos tendo como linha teórica os postulados dos Estudos Culturais ${ }^{4}$ e da Teoria da

\footnotetext{
${ }^{1}$ Mediação é um conjunto de influências provenientes tanto da mente do sujeito como de seu contexto sociocultural - incluindo as intervenções dos agentes sociais e das instituições - que estruturam o processo do conhecimento (OROZCO-GÓMEZ, 1991).

${ }^{2}$ Esta pesquisa adota a definição de populações caboclo-ribeirinhas de Ftaxe (2004).

${ }^{3}$ A RDS Mamirauá está localizada na confluência dos rios Solimões, Japurá e Auati-Paraná, a $450 \mathrm{~km}$ de Manaus. Foi criada pelo decreto estadual no 12.836 de 9 de março de 1990 e possui uma área de 1.124.000 hectares.

${ }^{4}$ Segundo Johnson (2000), os Estudos Culturais compreendem uma área de investigação e intervenção que toma como objeto qualquer artefato que possa ser considerado cultural sem fazer distinção entre 'baixa' e 'alta cultura'.
} 
Recepção. ${ }^{5}$ Portanto, as práticas de recepção foram analisadas tendo como pando de fundo o discurso conservacionista difundido pelos extensionistas do Instituto de Desenvolvimento Sustentável Mamirauá ${ }^{6}$ (IDSM) e as práticas de vida dos moradores da comunidade de São Raimundo do Jarauá, agentes com os quais o referido trabalho estabeleceu relações por meio de pesquisa empírica.

\section{Recepção e mediação}

Orozco-Gómez (1991) propõe uma metodologia para o estudo das mediações. A pergunta que orienta esta proposta metodológica é: "como se realiza a interação entre o discurso e a sua audiência?". Investigar, nesta linha, requer assumir a audiência como sujeito e considerá-la condicionada individual e coletivamente. Nesse sentido, segundo Fogolari (2001), o estudo parte do princípio de que a matriz de significados de uma mensagem não se encerra no seu próprio código, mas reside na experiência concreta das pessoas, nas suas histórias e projetos de vida, nas suas diferentes posições de classe e nas muitas mediações sociais do cotidiano, alimentadas por representações sociais.

Convém aqui explorar melhor os conceitos de receptor, recepção, mediação e suas conexões com cotidiano dos moradores. Em relação aos receptores:

Entendemos o receptor como: o ser "empiricamente [...] colocado numa zonalimite e conflitiva: de um lado é o sujeito-indivíduo, o apelo a usufruto, ao valor do uso dos bens da sociedade disponível; do outro lado é sujeito-social [...]. O receptor se confunde ora com o consumidor social, ora com o desbravador de si mesmo" (SOUSA, 1995, p.54).

Nesse sentido, o receptor é tratado nessa pesquisa como um ser ativo, ou seja, um ator no seu meio social que interfere no processo de recepção remodelando-a de acordo com suas vivências particulares e grupais. Logo, a recepção será sempre diversa para diferentes pessoas, como sugerem os Estudos Culturais. Tal perspectiva abre caminho para rupturas e novas abordagens segundo outros olhares e novos questionamentos (SOUZA, 1995). No caso específico desta pesquisa, os receptores são os moradores da comunidade de São Raimundo do Jarauá.

\footnotetext{
5 Os teóricos da Teoria da Recepção consideram os receptores das mensagens mais do que apenas depositários de informações, mas sim seres capazes de reformular conceitos baseados em fatores individuais (cultura, posição social etc), (JAUSS, 1989).

${ }^{6}$ O IDSM é responsável pela gestão da RDS Mamirauá.
} 
No tocante a recepção, partilhamos da definição de Martín-Barbero (1997), quando este ressalta que o estudo sobre tal temática quer resgatar a iniciativa, a criatividade dos sujeitos, a complexidade da vida cotidiana como espaço de produção de sentido, o caráter lúdico e libidinal na relação com os mesmos. O autor afirma ainda que:

O estudo da recepção ao contrário do que postulam as propostas funcionalistas, não buscam medir a distância entre a mensagem e seus efeitos, mas construir uma análise integral do consumo que é entendido como conjunto dos processos sociais de apropriação dos produtos, inclusive os simbólicos. Outra realidade é descortinada quando se ouvem os relatos dos setores populares. É aí que se revelam a criatividade e a liberdade (MARTÍN-BARBERO, 1997, p.87).

Em se tratando das mediações e da importância do cotidiano, Fogolari (2000) define mediação como algo equivalente a um sistema de regras e de operações aplicadas a qualquer conjunto de fatores ou coisas pertencentes a planos heterogêneos da realidade, para introduzir uma ordem. Portanto, "mediação significa que entre estímulo e resposta há um espesso espaço de crenças, costumes, sonhos, medos, tudo que configura a cultura cotidiana" (FOGOLARI, 2000, p.55). Na mesma linha, Martín-Barbero diz que é nas práticas cotidianas que está a chave para a recepção. Elas configuram uma arena onde conflito e consenso se estabelecem e onde os embates políticos são produzidos. Ele (cotidiano) não é insignificante, despolitizado, tampouco insuficiente para compreender a dinâmica da sociedade.

Deslocando essas reflexões para o objeto desta pesquisa, é possível pensar que o processo de recepção o (re)significação do discurso conservacionista pelos moradores de São Raimundo do Jarauá é fortemente influenciado pelas práticas cotidianas. São nas práticas da vida cotidiana, espaços em que os sentidos se configuram como lócus de investigação dos Estudos Culturais, que o fracasso e o sucesso, o belo e o feio, o bom e ruim encontram razão de ser ou não. Daí por que o cotidiano é, de forma privilegiada, espaço de (re)significação de sentidos da vida. É nele que o conjunto de significação produzido pelo homem ganha sentido, mostra-se, desse modo, como um lugar fundamental dos estudos da comunicação.

\section{A paisagem da pesquisa: São Raimundo do Jarauá}

A paisagem desta pesquisa foi eminentemente desenhada pelas águas e ainda nos dias de hoje elas a tudo influenciam. Segundo Ayres (1995), a Reserva de 
Desenvolvimento Sustentável Mamirauá (RDSM) está localizada em uma região denominada como várzea amazônica, ${ }^{7}$ cujos terrenos são predominantemente de origem pleistocênica, com mais de 100 mil anos de idade, e se formaram no final do período terciário, quando surgiu os Andes e se formou o grande lago amazônico. Este tipo de ecossistema está associado aos rios de água branca (como o Amazonas, Purus, Juruá e Japurá) que têm origem andina e carregam grande quantidade de sedimentos. Atualmente, estimasse que a Amazônia (AYRES; MOURA; LIMA-AYRES, 1994), possuidora de uma superfície de 368.989.221 hectares, tenha cerca de 200 mil quilômetros de matas inundáveis, aonde as terras chegam a alagar de 11 a 12 metros durante cerca de seis meses.

O último levantamento demográfico das áreas de várzea localizadas na RDSM foi realizado em 2001. De acordo com os dados do senso (MOURA, 2001), a população total da chamada área focal ${ }^{8}$ da reserva é de 1.585 habitantes, distribuída em 21 assentamentos localizados dentro dos limites da RDSM. A pesquisa também quantificou em 4.401 os moradores das 42 comunidades situadas na área de entorno da unidade de conservação e que são usuários dos recursos naturais da mesma. No total, existiam, a época, 6.306 pessoas residindo em 63 assentamentos dentro e no entorno da reserva. Os dados do senso relacionado à área subsidiária ${ }^{9}$ da RDSM revelaram uma população de 4.244 moradores, 60 comunidades, 17 sítios e 91 casas isoladas (a média de domicílios das comunidades era 9 com cerca de 6 pessoas em cada).

São Raimundo do Jarauá ${ }^{10}$ está situada em terras de várzea inundáveis localizadas na margem direita do rio Jarauá, próxima a confluência com o rio Japurá, em um dos setores da reserva de mesmo nome ${ }^{11}$. Segundo o mapa político do Estado, Jarauá

\footnotetext{
7 A Amazônia possui grande variedade de ecossistemas, dentre os quais se destacam: matas de terra firme, florestas inundadas, várzeas, igapós, campos abertos e cerrados (IBAMA, 2004, disponível em www.ibama.gov.br).

${ }^{8}$ A área focal da RDSM compreende um território de 260.000 hectares onde são implementados todas as ações do Instituto de Desenvolvimento Sustentável Mamirauá (IDSM) com objetivo de conciliar preservação do meio ambiente e a qualidade de vida das populações tradicionais residentes.

${ }^{9}$ A área subsidiária da RDSM abrange 864.000 hectares de um território cujas ações do IDSM ainda não estão sendo implementadas.

${ }^{10}$ A comunidade de São Raimundo do Jarauá é conhecida entre os moradores da reserva simplesmente como Jarauá.

${ }^{11}$ A Área Focal da RDSM possui nove setores: Jarauá, Aranapu, Boa União, Barroso, Horizonte, Liberdade, Tijuaca, Mamirauá e Ingá. O setor Jarauá compreende as comunidades de São Raimundo do
} 
localiza-se no território do município de Uarini, mas é efetivamente atendida pelo poder público municipal de Alvarães. Segundo o último senso demográfico feito na reserva (2001), a população na época (141 habitantes distribuídos em 22 domicílios) era jovem (a maioria com menos de 24 anos), a maior parte composta por homens (54\%). Como seria de se esperar, o trabalho de campo, realizado nos anos de 2004 e 2005, revelou o aumento no número de casas em relação ao senso de 2001. Foram contadas 30 residências, sendo que vinte e seis construídas em terra e quatro são flutuantes.

\section{As mediações do discurso conservacionista em Jarauá}

\section{O medo}

A descrição das mediações do discurso conservacionista em São Raimundo do Jarauá segue o modelo proposto por Fogolari (2001), ou seja, traz à tona os principais elementos mediadores presentes nos discursos dos comunitários captados por meio das entrevistas $^{12}$. O primeiro a ser apresentado é o sentimento de medo manifestado pelos moradores em relação aos seguintes fatores: a perda da sua principal fonte de sustento, os recursos pesqueiros; a possível retirada das populações tradicionais da área da reserva; e as mudanças comportamentais que seriam necessárias em razão do estabelecimento de regras para o acesso aos recursos naturais após a implantação da RDS.

Debray (1994) aponta as emoções (neste caso o medo) como o caminho comum que os indivíduos percorrem nas relações que fomentam processos mediadores. A emoção é vista de maneira privilegiada, pois também motiva e sustenta as trocas entre emissão e recepção.

Emoção é o regime de movimento que se estabelece no corpo sem a permissão da vontade e que muda de repente os pensamentos. Podemos distinguir dois tipos de emoção: uma, a desprendida e sutil, que se apresenta na alegria, no sorriso; outra, a reprimida e sufocada, que se manifesta no medo e na cólera (NOVAES, 1999, p.89)

A mudança de pensamento ocasionada pelas emoções, como enuncia Novaes, pode ser percebida nos depoimentos dos moradores de Jarauá. Assim como ocorreu em outras

Jarauá, Manacabi, Nova Colômbia e Pirapucú, sendo o maior da reserva em área geográfica, aproximadamente 80 mil hectares.

${ }^{12}$ Entre comunitários foram realizadas 20 entrevistas, enquanto que junto aos extensionistas apenas duas. 
localidades da reserva, as resistências ${ }^{13}$ à implantação da RDSM foram grandes. Parte delas deveu-se aos boatos disseminados por pescadores comerciais e outros setores econômicos e políticos, que não tinham interesse na instalação de uma RDS na várzea de Mamirauá, de que haveria a retirada das populações tradicionais. No entanto, o discurso conservacionista, levado aos comunitários por pesquisadores/extensionistas, conseguiu prevalecer tendo como mediador outro temor: dos moradores de ficarem em pouco tempo sem comida e trabalho devido ao esgotamento dos estoques pesqueiros em razão da pesca comercial.

Quando Mamirauá chegou, nós já estávamos pedindo socorro. Eu era uma dessas pessoas. Isso aqui era cheio de fachiador ${ }^{14}$. Os peixes estavam sumindo. Hoje ainda não está fácil não. A gente dizia o seguinte: o negócio agora mudou, existem critérios e limites. Eu gostei demais, porque antes matavam budegos ${ }^{15}$ pequenininhos. Não tinha ninguém que dissesse se era bom ou não e as pessoas compravam. (Antônio Daniel Carvalho, morador e primeiro presidente da Comunidade de São Raimundo do Jarauá, 19/11/2004)

Diante dos relatos, e lavando em consideração que as mediações se dão na relação indivíduo, práticas culturais e discurso conservacionista, o temor presente nas narrativas acima se justifica quando levamos em consideração o cotidiano dos comunitários. De acordo com Moura (2004), a pescaria é a principal fonte de renda na várzea de Mamirauá, sendo fortemente influenciada pela variação do nível da água. Nos período de seca a produção e, consequentemente os rendimentos, aumentam, enquanto que na cheia traz consigo um período de recursos escassos devido a maior dispersão dos cardumes. "Na época não tinha mais condições de viver, porque os peixeiros entravam nos lagos e lavavam tudo, e a única alternativa que restava era a farinha" (Romeu Rosamir dos Santos Marinho, presidente da Associação dos Produtores do Setor Jarauá (APSJ), 27/11/2004).

As falas dos entrevistados apontam no sentido de que as conversações entre pesquisadores/extensionistas e comunitários de Jarauá respeito da possível criação da

\footnotetext{
${ }^{13}$ Dos entrevistados para esta pesquisa, $100 \%$ afirmaram que as resistências à implantação da reserva foram grandes e que foram superadas graças ao trabalho dos extensionistas/líderes comunitários junto às comunidades.

${ }^{14}$ Termo que designa pescadores noturnos que utilizam o facho de luz de lanternas para localizar os peixes e depois capturá-los com arpões.

${ }^{15}$ Budego é o nome vulgar utilizado pelos caboclos para designar os filhotes de pirarucu.
} 
RDSM aconteceram num momento em que o temor de ficar sem comida e trabalho, por causa da pesca comercial, confrontava-se com o medo da criação da reserva significar a retirada dos moradores de suas casas ou em mudanças drásticas em seus usos e costumes. De um lado, a certeza do esgotamento dos estoques pesqueiros pelos barcos de pesca e suas conseqüências caso a situação se mantivesse a mesma. De outro, as incertezas quanto ao grau de mudança no modo de vida dos moradores que fatalmente traria a implantação da reserva. Em meio a esse dilema, os relatos apontam no sentido de que o projeto conservacionista da RDS, disseminado pelos extensionistas, mais especificamente aqueles cujo prestígio $^{16}$ junto às comunidades estava solidificado, foi percebido pelos comunitários como o "menor dos males" frente ao problema maior das invasões dos lagos por pescadores comerciais e o conseqüente esgotamento dos recursos pesqueiros.

A resistência foi grande, mas o nosso presidente, Antônio Martins, era uma pessoa muito experiente mesmo, sabia como começar uma reunião e lidar com as pessoas. Em toda reunião ele tentava fazer as pessoas entender que não ia ser assim como diziam, ou seja, ninguém ia ser expulso da sua casa. Foi difícil porque as pessoas falavam contra na reunião, diziam que os macaqueiros viriam buscar a produção de avião. Falavam muitas coisas. A minha família nunca foi contra, porque o Antônio era meu padrasto e ele sempre sentava com a gente e explicava como iam ser as coisas. Na reunião eu só ficava calada porque ele era quem sabia das coisas. O pessoal do Instituto sempre vinha aqui nas reuniões, mas quando eles viram que o Antônio dava conta mesmo deixaram mais de aparecer. (Maria Lene de Souza Carvalho, 32, morador de São Raimundo do Jarauá, 28/11/2004)

Tendo em vista o exposto acima, o medo figurou como importante mediador do discurso conservacionista quando da decisão dos moradores em aderirem ao projeto da RDS e, consequentemente, adotarem práticas sustentáveis no uso dos recursos naturais. A escolha dos moradores em aderir a ao projeto conservacionista ao invés de continuarem enfrentando o risco de esgotamento dos recursos pesqueiros, fica mais clara quando levamos em consideração que dentre os entrevistados para esta pesquisa, 70\% declararam que tiveram de mudar seus hábitos relacionados à caça e a pesca depois da implantação

\footnotetext{
${ }^{16}$ A confiança dos moradores nos líderes comunitários e nas lideranças ligadas à Igreja Católica provém dos trabalhos de preservação de lagos e organização comunitária realizados pelo MEB e GPD nos anos 70 e 80. As invasões de barcos pesqueiros nos lagos de Jarauá se intensificaram em 1972, ano em que o religioso Irmão Falco deu início à organização das comunidades para protegerem seus lagos no município de Jutaí. A experiência espalhou-se rapidamente pela várzea de Mamirauá. Embora o movimento tenha se expandido, a falta de respaldo legal para impedir a pesca comercial de invadir os lagos fez com os estoques naturais continuassem a ser explorados de forma predatória.
} 
da reserva. No entanto, $85 \%$ deles consideram que valeu à pena em razão do aumento dos estoques pesqueiros devido a proibição da entrada embarcações comerciais na área da reserva.

\section{Lembranças dos tempos de fartura e escassez}

As lembranças da fartura da caça e da pesca em Jarauá nos primeiros anos de sua ocupação, bem como a escassez trazida pela chegada dos caçadores e pescadores comerciais à localidade, descrita no tópico anterior, também atuam como mediadores do discurso conservacionista. De acordo com Bosi (1997), relembrar os passado é, também, fazer parte deles ou, ao menos, deles se aproximar, ou seja, implica em levar o indivíduo a uma dimensão temporalizada onde passado e o presente se cruzam e se completam. Para a pesquisadora, a memória aparece como força subjetiva e ao mesmo tempo profunda e ativa, latente e penetrante, oculta e invasora. "Através da memória o passado se conserva e atua no presente pelos materiais que estão, agora, a nossa disposição" (FOGOLARI, 2001, p.164). Tanto os moradores mais antigos quanto aqueles que não vivenciaram a época de abundância dos recursos naturais em Jarauá, relatam como era a vida antes da redução dos estoques naturais de peixes pela pesca comercial:

\footnotetext{
Antes a gente morava na Prainha e metade do pessoal vei para cá e outra se estabeleceu numa outra comunidade. Só que eles vinham de lá pescar aqui, porque onde a comunidade está é a boca de um lago e na época tinha fartura de caça e pesca. Então, propus a eles de virem logo morar aqui, porque eles faziam um caminho longo até chegar no lago para pescar. E eles vieram. (Antônio Daniel Carvalho, morador e primeiro presidente da Comunidade de São Raimundo do Jarauá, 19/11/2004)
}

O relato acima é um morador com mais de 20 anos de residência na reserva. Este fato não causa estranheza, já que em uma sociedade como a nossa, que vive sob a lógica da produção, do descartável, o ato de lembrar é uma atividade mais frequentemente exercida pelos idosos. No entanto, entre os entrevistados para esta pesquisa, $100 \%$ fazem referências às lembranças da época de fartura embora muitos deles não as tenham vivenciado. De acordo com Halbaechs apud Bosi (1997), isso acontece porque os mais 
novos filiam-se a uma memória coletiva desenvolvida a partir de laços de convivência familiar, escolar e profissional.

Ela (memória coletiva) entretém a memória de seus membros (memória individual ${ }^{17}$ ) que acrescenta, unifica, diferencia, corrige e passa a limpo. Vivendo no interior de um grupo sofre vicissitudes da evolução de seus membros e depende de sua interação. (BOSI, 1997, p.411)

Segundo Halbaechs, para que um ou vários indivíduos contem e recontem acontecimentos passados sem os terem vivido, é necessária a existência de um narrador antecedente de grande competência. Este narrador, que vivenciou os fatos narrados, agrega às suas lembranças conhecimentos individuais, incide sobre as relações sociais e ajuda a constituir a memória coletiva do grupo no qual está inserido.

Por meio da comunicação oral e de um discurso socializador, os grupos integram-se à vida social expressando relatos, a síntese existencial do passado, do presente e do futuro, isto porque o caráter plural dos costumes, padrões, dos valores, das crenças, dos hábitos, das emoções e sensações que constituem o cotidiano dos seus antepassados e familiares foram trazidos à tona. (FOGOLARI, 2002, p.173)

Em Jarauá, encontramos alguns moradores cujo discurso reúne as características citadas acima por Fogolari, dentre eles destaca-se Antônio Daniel Carvalho. Seo Toinho, como é conhecido, foi o primeiro morador da comunidade, onde chegou em 1963, alfabetizou a maioria da população adulta de Jarauá, foi o primeiro presidente da associação de moradores em 1983 e atuou como extensionista em Mamirauá nos primeiros anos de implantação da RDS. O pescador, e agricultor no tempo da cheia, é uma referência para os demais moradores quando o assunto se refere ao processo de aceitação pela comunidade da implantação da reserva e os motivos que embasaram tal decisão:

Quando se formou esta comunidade, eu fiz os cursos na igreja de como levar uma comunidade, pois ninguém queria assumir nada. Então, eu era secretário, tesoureiro, presidente, professor e catequista. Sozinho. Passaram-se quatro anos assim e eu resolvi chamar o pessoal e dividir as tarefas, pois tinha gente que falava mal e outras falavam bem e era melhor ter mais pessoas

\footnotetext{
${ }^{17}$ Articulando memória coletiva e memória individual, BOSI afirma que cada memória individual é um ponto de vista sobre a memória coletiva.
} 
trabalhando. O povoado aqui começou a crescer mesmo em 1980, e foi quando a coisa ficou feia devido as invasões dos pescadores. Aqui já não se achava quase o que pescar. É pó isso que toda vez que chega alguém novo aqui a gente conta como era antes e como a coisa ficou ruim quando não tinha regra pra nada. Isso é para as pessoas entenderem porque aqui tudo é regrado". (Antônio Daniel Carvalho, morador e primeiro presidente da Comunidade de São Raimundo do Jarauá, 19/11/2004)

"Seo Toinho" e outros moradores mais antigos ajudaram a construir a memória coletiva da comunidade de Jarauá em relação às épocas de abundância e escassez atuando como líderes comunitários, professores e extensionistas. Parece ser esta uma das principais razões para que todos os entrevistados citem a fartura de peixes e depois a drástica redução dos estoques naturais devido à pesca comercial em seus depoimentos, enquanto que apenas $15 \%$ deles possuem tempo suficiente de residência na RDS para terem vivenciado tais fatos.

Tendo em vista os relatos dos moradores e levando em consideração os postulados de Bosi e Fogolari, pode se afirmar que as lembranças da época de abundância e da pesca predatória fazem os moradores tomarem posições em relação ao presente e ao futuro. Relembrar o estado quase intacto do meio ambiente antes da exploração predatória dos recursos pesqueiros, faz com que os moradores tomem atitudes no presente, como a adoção do manejo sustentável da pesca, com objetivo de alcançar uma situação de disponibilidade de peixes semelhante àquela existente nos primeiros anos de ocupação humana de Jarauá.

\section{Utopia e sonho de uma vida melhor}

O último elemento mediador do discurso conservacionista descrito nesta pesquisa diz respeito à utopia e ao sonho dos moradores de Jarauá em relação a uma melhor qualidade de vida. Em seus depoimentos, os comunitários deixaram claro que o projeto da RDS, disseminado principalmente pelos extensionistas, alimentou esperanças de melhorias no acesso a serviços públicos básicos como saúde e educação e de ascensão social. Logo, a utopia e o sonho atuaram como mediadores na medida em que várias pessoas, como veremos nos depoimentos, apostaram e ainda apostam no projeto 
conservacionista de Mamirauá tendo em vista benefícios futuros, notadamente, o aumento da renda familiar.

Antes de analisarmos os depoimentos, faz-se necessário tornar claros os conceitos de utopia e sonho utilizados na pesquisa. A utopia está presente na vida dos grupos sociais desde tempos imemoriais, tanto nas chamadas sociedade primitivas (préhistóricas) quanto no pensamento religioso das mais antigas sociedades históricas. $\mathrm{Na}$ verdade, a utopia justifica a presença do homem no meio social:

O que nos mantém em plena e ininterrupta ação construtiva, que dá sentido a vida atual é que hoje e agora construímos o mundo de amanhã. E dialeticamente é esta atividade que faz com que a esperança seja um objetivo realizável. (COELHO apud HERKENHOFF, p.19)

O enunciado de Coelho nos leva a um dos conceitos de utopia que a relaciona a tudo o que era, deixou de ser, tudo o que será, mas não é ainda. Portanto, de acordo com esse conceito, ela nos projeta para algo que ainda não é, mas que poderá vir a ser. "Tratase, por conseguinte, de uma virtualidade, isto é, algo que existe de forma embrionária e cujo desenvolvimento será distinto de acordo com as condições que o processo ocorrer" (FOGOLARI, 2002, p.175). O virtual citado por Fogolari é definido por Lévy (1997) como algo que existe potencialmente, mas que não se opõe ao real, ou seja, a utopia é uma espera que se concretiza no sonho e que se coloca em ação num futuro próximo, onde enfim se tornará realidade. Essa espera, esse vir a ser "é o ponto de contato entre a vida e o sonho, sem o qual o sonho é uma droga narcotizante" (COELHO, 1981, p.9). Logo, o conceito de utopia aqui trabalhado nos leva a concluir que a imaginação utópica não é delirante ou fantástica. Ela parte de fatores subjetivos elaborados inicialmente no âmbito individual, para ter a seguir uma conotação social, portanto, pontuada por fatores objetivos.

A utopia vivida em Jarauá nos momentos que antecederam a criação da RDS e ainda nos dias de hoje se insere na acepção mais vasta da palavra ${ }^{18}$, pois não se vincula a um mito ou a uma fantasia solta. Para os moradores, a utopia de vida melhor após a criação da reserva, e enquanto a mesma existir, trata-se daquilo que não existe, mas que já aconteceu em parte e está na eminência de acontecer na totalidade. Logo, como

\footnotetext{
${ }^{18}$ Segundo Herkenhoff (1990), utopia significa a antevisão de um projeto. 
veremos a seguir, os relatos coletados demonstram que a aceitação de alguns elementos do ideário conservacionista e as conseqüentes mudanças comportamentais em relação à exploração dos recursos naturais tiveram como mediadora a utopia de uma vida melhor.

Para entender melhor com se dá esse processo de mediação, novamente precisamos entender o cotidiano e contexto no qual ela acontece. Conforme vimos anteriormente, durante as discussões sobe a criação da reserva Jarauá enfrentava uma crise na principal fonte de renda comunidade: a pesca. Além disso, a localidade já sofria com o isolamento e a falta de políticas públicas voltadas para a educação, saúde e saneamento básico, situação comum nos vários rincões da Amazônia. Em meio a este cenário pouco promissor, surge o discurso dos extensionistas da RDS alimentando uma utopia de uma reserva que se propunha a aliar a conservação dos recursos naturais e a melhoria da qualidade de vida das populações tradicionais residentes. Neste momento, a utopia contida no discurso conservacionista se mistura com a realidade, estimulando os indivíduos à concretização dos seus desejos e sonhos: emprego, renda, saúde, educação e uma vida melhor para os filhos:

Eles (homens) aceitaram logo a reserva porque acharam que era bom negócio. Foi difícil todos aceitarem, algumas famílias não concordavam. Meu esposo vive mais da pesca, nós plantávamos roça, mas não dava lucro nenhum porque enchia e alagava. Hoje não pode tirar peixe como a gente quer, mas dá pra tirar algum dinheiro. (Maria Janete Mendonça, moradora da São Raimundo do Jarauá, 11/28/2004)

No meu caso, antes de começar a reserva eu plantava muita roça de mandioca, jerimum, melancia e milho para se manter. Depois que formou a reserva eu comecei trabalhando com o Instituto como cozinheira por cinco anos, e cuidava da roça nas minhas folgas. O meu marido trabalhou muito com os pesquisadores. Depois da reserva melhorou para mim porque eu consegui um trabalho, isso aí para mim já foi bom porque antes não existia emprego. Agora, aqui e acolá aparece um trabalho. (Maria Lene de Souza Carvalho, moradora de São Raimundo do Jarauá, 28/11/2004)

Em um segundo momento após a criação da RDSM, os resultados do manejo sustentável da pesca estimulou os moradores de Jarauá a apostarem na utopia de melhor qualidade de vida da RDS.

Mudou muita coisa depois da reserva, principalmente os problemas dos peixes. A gente antes não tinha mais como pegar um pirarucú com facilidade, agora não. A gente viu que tá multiplicando muito e os pescadores estão ganhando mais. Por isso eu passei a gostar da reserva, que antes eu tinha medo. (Vanda Andrade, moradora de São Raimundo do Jarauá, 11/26/2004) 
O relato acima ilustra o impacto do manejo sustentado de pirarucu, que teve início em 1998, na economia de Jarauá. Segundo o Programa de Alternativas Econômicas do IDSM (ESTUPIÑA, 2004), o lucro de cada pescador na reserva subiu de R $\$ 402,46 \mathrm{em}$ 1999 para $\mathrm{R} \$ 766,8$ em 2002. No caso específico de Jarauá, o aumento é mais significativo, pois saiu de $\mathrm{R} \$ 300$ para $\mathrm{R} \$ 1.000,00$.

Um terceiro elemento a sustentar a utopia social dos moradores foi o acesso a saúde e a educação. Jarauá, a exemplo de outras comunidades ribeirinhas, tinha pouco ou nenhum acesso ao ensino formal e a atendimento médico. Após a implantação da reserva, foi criada a Coordenação do Programa Qualidade de Vida ${ }^{19}$ (CQV) na estrutura do IDSM, cujo objetivo é desenvolver ações voltadas para educação ambiental, educação para ciência, saúde comunitária, tecnologias apropriadas e comunicação. Embora ainda exista muito a ser conquistado nestas áreas, os moradores, como podemos constatar nos depoimentos abaixo, perceberam algumas melhorias (MOURA, 2004) como: redução da mortalidade infantil e do parasitismo intestinal; aumento do percentual de alunos da primeira a quarta séries; fomento de iniciativas de educação ambiental nas comunidades (destino do lixo, arborização da comunidade, diminuição das invasões internas nas comunidades, lagos e praias); e aumento do número de alunos das escolas urbanas e rurais de ensino fundamental e ensino médio participando das atividades de educação para ciência.

Ao analisar os depoimentos e os dados de incremento da renda familiar e o início do acesso a serviços públicos básicos acima, é preciso destacar que em Jarauá, bem como localizada em países capitalistas, desenvolvidos ou não, a ascensão social através do aumento da renda constitui-se como uma utopia social. Apesar das utopias sociais estarem ligadas sempre às questões culturais e históricas das nações, em qualquer outra comunidade também está presente algo que é comum em todo sistema capitalista: a promessa de ascensão social possível para todos. Neste sentido, segundo Fogolari (2002), sonhos, utopias e imaginário se situam, pois, no limite de práticas culturais diversas, mas envolvem algo que as transcendem: o ideal capitalista.

\footnotetext{
${ }^{19}$ A CVQ está subordinada à Diretoria das Alternativas Econômicas e integrada à Coordenação da Organização Política e Sócio-Econômica (COPSE) do IDSM.
} 
Este ideal capitalista vem sendo alimentado por alguns avanços no aumento da renda dos moradores e no acesso a serviços básicos de saúde e educação. No entanto, este ideal continua sendo uma utopia social se levarmos em consideração que $80 \%$ dos entrevistados afirmam passar por privações econômicas, 65\% considera as atuais alternativas econômicas insuficientes para garantir o sustente da família, 100\% dizem não ter atendimento médico preventivo na comunidade, $100 \%$ não têm água encanada em casa e 55\% gostaria de explorar mais os recursos naturais da reserva para suprir suas necessidades, mas são impedidos pelas regras de uso dos recursos adotadas na RDS. Os dados reforçam o entendimento de que a utopia de melhor qualidade de vida dos moradores de Jarauá parte sim fatores subjetivos (a espera pela resolução dos problemas que começaram a ser equacionados), mas está embasada por fatores objetivos (as melhorias descritas acima). Sob este olhar, a utopia de uma vida melhor é percebida pelas pessoas como metodologia crítica e instrumento de ação e, como tal, importante mediadora do discurso conservacionista em Jarauá.

\section{Conclusões}

A pesquisa buscou identificar e analisar as mediações do discurso conservacionista com objetivo de aproximar-se das razões que levaram os moradores de Jarauá a adotar práticas sustentáveis. A investigação, no entanto, não tratou de medir a distância entre as mensagens veiculadas pelos extensionistas do IDSM e seus efeitos, mas contribuir com uma análise atenta da apropriação (consumo) das mesmas, pois, conforme postula Martín-Barbero (1997), outra realidade é revelada quando se ouvem os relatos dos setores populares. Por esta razão, os comunitários foram tratados como seres ativos capazes de interferir no processo de recepção e remodelá-lo de acordo com suas vivências particulares e grupais. Os resultados obtidos parecem corroborar com a hipótese norteadora do trabalho, de que conhecer as mediações do discurso conservacionista permitiria lançar uma luz sobre os motivos de Jarauá ter obtido um sucesso singular dentro da RDS na adoção e implementação de métodos sustentáveis de exploração dos recursos naturais. 
O resultado desta pesquisa não pretende atingir conclusões generalizantes, mas evidenciar que o discurso conservacionista dirigido aos moradores de Jarauá por meio do extensionismo não foi e não está sendo recebido acriticamente. Na verdade, os relatos apontam na direção de que os agentes sociais (moradores/receptores) compartilham valores quando submetidos ao ideário conservacionista, ou seja, eles negociam diante das narrativas. Enquanto o IDSM esforçou-se e ainda esforça-se para transmitir os principais elementos da proposta conservacionista, os comunitários enxergaram na proposta de criação e manutenção da RDS uma oportunidade de manterem-se em suas terras, se proteger contra os invasores e melhorarem suas condições de vida. Neste contexto, eles tornam-se atores, são sujeitos de um processo valorativo e político onde os sentidos não foram e não são impostos pelos extensionistas do IDSM, mas negociados.

Finalmente, a pesquisa foi idealidade e executada com a crença de que compreender como se dá a recepção, a apropriação das mensagens, a constituição social dos sentidos e encontrar alternativas de comunicação é trabalhar para ampliar a troca cultural de maneira democrática, para fazer efetiva a pluralidade e a diferença que enriquecem a sociedade.

\section{Referências Bibliográficas}

AYRES, José Márcio (1995). As várzeas do Mamirauá. MCT-CNPq, Sociedade Civil Mamirauá.

AYRES, José Márcio (1993). As Matas de Várzea do Mamirauá. CNPq e Sociedade Civil Mamirauá, Brasília.

AYRES, José Márcio; MOURA, Edila F.; LIMA-AYRES, D. de M (1994). Estação Ecológica Mamirauá: o desafio de preservar a várzea na Amazônia. In: Trópico em Movimento: alternativas contra a pobreza e a destruição ambiental no trópico úmido. Belém: UFPA, POEMA.

BOSI, Ecléa (1997). Memória e sociedade. São Paulo, Companhia das Letras.

COELHO, Teixeira (1981). O que é utopia? São Paulo, Brasiliense.

DEBRAY, Régis (1994). Vida e morte da imagem. Petrópolis, Vozes, 1994. 
ESTUPIÑAN G (2004). Monitoramento do programa de comercialização de pescado (PCP). In: Simpósio Interno de Monitoramento - SIM, 2 , Tefé, 2004. Apresentação de palestra. Tefé: IDSM-OS/MCT.

FOGOLARI, Élide Maria (2000). O visível e o invisível no ver e no olhar a telenovela: recepção, mediação e imagem. São Paulo: Paulinas.

FRAXE, Therezinha de Jesus Pinto (2004). Cultura caboclo-ribeirinha: mitos, lendas e transculturalidade. São Paulo: Annablume.

HERKENHOFF, João Batista (1990). Direito de Utopia. São Paulo, Acadêmica.

JAUSS, Hans Robert (1989). “La Ifigenia de Goethe y la de Racine”. In: WARNING, Rainer (org). Estética de la receotión. Colección La Balsa de le Medeive, 31. Tradução: Ricardo Sanchez Ortiz. Madri: Visor.

LÉVY, Pierre (1997). O que é virtual? São Paulo, Unicamp.

LIMA-AYRES, Deborah, ALENCAR, Edna Ferreira (1994). Histótico da ocupação humana e mobilidade geográfica de assentamentos na área da Estação Ecológica Mamirauá. In: IX Encontro Nacional de Estudos Populacionais, 1994, Belo Horizonte. Anais. Belo Horizonte. pp.535-382.

LIMA-AYRES, Deborah (1992). The social Category Caboclo - history, social organization, identidy and outsider's social classification of the rural population of an Amazonian region (the middle Solimões). $\mathrm{PhD}$ dissertation, University of Cambridge.

MARCONI, Maria Andrade; LAKATOS, Eva Maria (2002). Técnicas de Pesquisa: planejamento e execução de pesquisas, amostragens e técnicas de pesquisa, elaboração, análise e interpretação de dados. $5^{\mathrm{a}}$ ed. São Paulo: Atlas.

MARTÍN-BARBERO, Jesus (1997). Dos meios às mediações. Rio de Janeiro, UFRJ.

MOURA, Edila (2004). Populações Humanas da Reserva de Desenvolvimento Sustentável Mamirauá. http://www.mamiraua.org.br/2-1-e.html. Acesso em: $27 \mathrm{dez}$ 2004.

MOURA, E. A. F (2004). Indicadores de qualidade de vida nas duas Reservas de Desenvolvimento Sustentável. In: Simpósio Interno de Monitoramento - SIM, $2^{\circ}$, Tefé, 2004. Apresentação de palestra. Tefé: IDSM-OS/MCT.

Original submetido em: 30/09/2013

Aprovado para publicaçãoo em: 30/10/2014. 
Sobre os autores

Allan Soljenítsin Costa

Graduação em Comunicação Social - Habilitação em Jornalismo pela Universidade Federal do Amazonas (Ufam), mestrado e doutorado em Sociedade e Cultura na Amazônia pela Ufam. Tem experiência na área de Comunicação, Jornalismo e Meio Ambiente. Professor do Curso de Jornalismo da Ufam.

Grace Soares Costa

Graduação em Comunicação Social - Habilitação em Jornalismo pela Universidade Federal do Amazonas (Ufam), mestrado em Sociedade e Cultura na Amazônia pela Ufam. Tem experiência na área de Comunicação, atuando, principalmente, nos seguintes temas: Jornalismo científico. Coordenadora do Curso de Comunicação do Social da Faculdade Martha Falcão (FMF) 